\title{
EKO-SPIRITUALISME: SEBUAH KENISCAYAAN PADA ERA KONTEMPORER
}

\author{
Frederikus Fios \\ Character Building Development Center, BINUS University \\ Jln. Kemanggisan Ilir III No. 45, Kemanggisan - Palmerah, Jakarta 11480 \\ fios2013@yahoo.co.id
}

\begin{abstract}
This paper provides a new perspective of looking at our natural environment with a spiritual perspective. The main argument of this paper was inspired by the emergence of the reality of our natural environment is increasingly damaged by the implications of a variety of viewpoints, attitudes and human behavior are destructive and counterproductive. The influences of modern science and philosophy have reduced logical meaning of the universe solely on technical functions-economical to fulfill the needs of humans (anthropocentric). In effect, we are witnessing the natural environment is being weakened only in different parts of the world. So this paper is an effort to return to the community awareness of the contemporary world that still cares for the future of our natural environment better. This paper provides an alternative framework as well as a new optimism for our natural environment lasting and sustainable return by optimizing intrinsic qualities inherent in every human being as a spiritual being. Then become eco-spiritual as a necessity for our contemporary world society today.
\end{abstract}

Keywords: ecology, spirituality, contemporary world

\begin{abstract}
ABSTRAK
Tulisan ini memberikan sebuah perspektif baru dalam memandang lingkungan alam dengan sudut pandang spiritual. Argumentasi utama munculnya tulisan ini terinspirasi oleh realitas lingkungan alam yang makin rusak akibat implikasi berbagai cara pandang, sikap, dan tingkah laku manusia yang destruktif dan kontraproduktif. Pengaruh sains modern dan filsafat logis telah meredusi makna alam semesta (universum) hanya semata-mata pada fungsi-fungsi teknis-ekonomis untuk memenuhi kebutuhan manusia (antroposentris). Efeknya, lingkungan alam makin rusak saja di berbagai belahan bumi. Tulisan ini merupakan suatu upaya penyadaran kembali kepada masyarakat dunia kontemporer yang masih mau peduli pada masa depan lingkungan alam yang lebih baik. Tulisan ini memberikan sebuah kerangka pikir alternatif sekaligus optimisme baru untuk lingkungan alam yang langgeng dan lestari dengan mengoptimalkan kembali kualitas hakiki yang inheren pada setiap manusia sebagai makhluk rohani-spiritual. Maka dari itu, jadilah eko-spiritual sebagai sebuah keniscayaan untuk masyarakat dunia kontemporer saat ini.
\end{abstract}

Kata kunci: ekologi, spiritualisme, dunia kontemporer 


\section{PENDAHULUAN}

Istilah lingkungan alam diinterpretasi penulis sebagai terminologi yang memiliki makna berbeda dengan lingkungan hidup. Menurut penulis, istilah lingkungan hidup hanya merujuk pada unsur biotik saja dalam alam sehingga agak diskriminatif terhadap hal-hal abiotik dalam alam. Oleh karena itu istilah lingkungan alam terkesan lebih tepat digunakan dalam tulisan ini ketimbang lingkungan hidup.

Istilah lingkungan alam memiliki banyak arti dan makna. Namun demikian, dari banyak makna itu kiranya disepakati bahwa lingkungan alam terdiri dari unsur-unsur biotik dan abiotik yang terdapat di dalam alam semesta (universum) ini. Unsur-unsur dimaksud di antaranya sinar matahari, tanah, udara, air, flora (tumbuhan), manusia, fauna (hewan), iklim, suhu, dan sebagainya. Tampak bahwa manusia hanya salah satu unsur di dalam konstelasi lingkungan alam ini.

Deskripsi tersebut memunculkan sebuah korelasi mendasar antara berbagai elemen di dalam lingkungan alam ini. Ada semacam rantai hubungan erat satu sama lain. Matahari memberikan sinar yang berguna untuk proses fotosintesis tumbuhan yang akhirnya menghasilkan daun dan buah yang bisa dikonsumsi oleh manusia dan hewan demi kelangsungan hidup. Siklus ini terus berlangsung sepanjang waktu untuk memastikan eksistensi kehidupan tetap ada (exist).

Jika salah satu unsur alam rusak/langka, dipastikan bagian lain juga dari alam ikut rusak, hancur bahkan punah-binasa. Misalnya saja ketika mata air di gunung mengering, tumbuhan, hewan, dan manusia otomatis-langsung terkena dampaknya. Krisis air akan melanda seluruh makhluk hidup yang membutuhkan unsur air sebagai sumber vital kehidupan. Ketika alam rusak atau dirusakkan, tamatlah riwayat hidup manusia dan seluruh makhluk hidup (biologis) dalam tatanan realitas alam semesta. Karena itu lingkungan alam mutlak dijaga, dipelihara, dilanggengkan. Inilah kewajiban moral dan sikap bijak yang penting disadari, dihayati, dan diamalkan segera dalam dunia kontemporer ini.

Menyadari pentingnya lingkungan alam bagi manusia dan makhluk hidup lain, muncullah sebuah kesadaran spiritual di kedalaman nurani dan bening budi manusia untuk peduli pada lingkungan alam. Menyelamatkan dan menjaga alam adalah bagian dari usaha manusia untuk menjaga keutuhan dan kelanggengan alam. Menjaga dan memelihara alam adalah bagian dari hidup iman dan keyakinan spiritual hakiki manusia. Sungguh tidak terpuji jika manusia sebagai makhluk yang memiliki jiwa, namun di sisi lain lupa (tidak peduli) terhadap dimensi lingkungan alam.

Tulisan ini berikhtiar mengembangkan sebuah refleksi dimensi spiritual manusia yang dikontekskan dengan realitas lingkungan alam kita. Maka jadilah sebuah konstruksi pemikiran sintesis "eko-spiritual" untuk lingkungan alam. Alur tulisan ini terdiri dari diagnosis masalah, solusi alternatif penyelesaian masalah, langkah praktis yang perlu diambil, dan hasil akhir.

\section{METODE PENELITIAN}

Karena merupakan sebuah refleksi kritis atas realitas lingkungan alam yang ada, metode penelitian ini menggunakan pendekatan analisis kualitatif. Menggunakan ketajaman analisis atas realitas lingkungan alam yang ada, ditopang oleh referensi yang relevan dengan topik yang dikembangkan, penulis melakukan sebuah konstruksi pemikiran filosofis mendalam untuk menemukan makna dan nilai-nilai penting yang perlu dikembangkan manusia dalam relasi dengan lingkungan alam. 
Penulis mengafirmasi gagasan-gagasan reflektif subjektif penulis dengan menggunakan referensi para pemikir terdahulu yang mewacanakan topik ini dalam buku yang terpublikasi. Refleksi penulis juga diperkaya dengan pemikiran penting para tokoh lain yang sudah menunjukkan kepedulian akademik mereka pada lingkungan alam melalui jurnal terkait topik bahasan ini. Dengan demikian, metode analisis kualitatif-kritis-hermeneutis mewarnai keseluruhan pembahasan ini.

\section{HASIL DAN PEMBAHASAN}

\section{Diagnosis Akar Krisis Lingkungan Alam Kontemporer}

Wajah carut marut lingkungan alam terus terjadi. Krisis energi, pemanasan global, bencana alam banjir dan topan, tingginya kadar polusi, menipisnya lapisan ozon, mencairnya lapisan es di kutub, hilangnya keanekaragaman hayati alam makin menggelisahkan masa depan manusia dalam locus lingkungan alam semesta sebagai tempat berpijak. Inilah tantangan utama yang sedang melanda manusia di era kontemporer saat ini. Tantangan ini sekaligus merumuskan diri sebagai masalah utama yang melanda bumi ini.

Jika dirunut secara analisis-logis-rasional, munculnya tantangan ini adalah sebagai konsekuensi logis dari sikap, cara pandang, dan perilaku manusia yang memandang alam secara teknis-ekonomis. Krisis lingkungan hidup global saat ini dilansir akibat dari paradigma ekonomis dalam memandang realitas empirik yang ditopang oleh pilar teknologi. Hanya saja karena teknologi adalah pilar ekonomi, dapatlah cara berpikir itu disebut sebagai cara berpikir tekno-ekonomis yang tampil dalam wajah homo techno-economicus (Binawan, 2010:195). Penggunaan teknologi untuk pemenuhan kebutuhan hidup manusia telah mengakibatkan kehancuran paling tragis terhadap kawasan lingkungan alam dewasa ini.

Kondisi lingkungan alam bumi terus menjadi masalah krusial yang melanda dunia dewasa ini. Krisis ekologi yang disebabkan oleh aktivitas pembangunan manusia membuat alam tempat manusia hidup menjadi tidak seimbang lagi. Bumi hampir di ambang kepunahannya jika tak mau dikatakan mencapai titik nadir menggelisahkan. Dan semua makhluk hidup, termasuk manusia, berada pada titik kritis jika tak mau dikatakan gawat-darurat. Dewasa ini banyak pihak mulai sadar untuk menyelamatkan masa depan bumi dari kepunahannya. Pada saat inilah pemikiran baru terhadap perlunya upaya pelestarian lingkungan alam menjadi penting.

Bisa dikedepankan dua penyebab utama krisis lingkungan alam dunia dewasa ini, yakni pada tataran hidup praktis dan pada tataran wilayah teori atau cara berpikir. Pertama, pada tataran praktis, kerusakan dan krisis alam muncul karena sikap dan perilaku manusia yang tidak berlandaskan nilainilai moralitas yang baik dalam mengembangkan relasi dengan alam. Model ini menunjukkan cara bersikap yang tidak ramah lingkungan yang berujung pada penciptaan pola relasi eksploitatif terhadap alam. Pola ini tak etis dari sudut pandang kebaikan lingkungan alam itu sendiri karena mengedepankan sikap tamak manusia. Kedua, pada tataran paradigma atau cara berpikir manusia, tentu tidak bisa lepas dari prinsip filosofi atau cara pandang manusia terhadap alam. Cara berpikir keliru pada alam secara eksplisit tergambar dalam perilaku tidak bijak dalam relasi manusia dengan alam. Mindset manusia yang keliru menjadi salah faktor penyebab kerusakan alam semesta.

Belakangan ini muncul kritik atas filsafat rasional (logika) yang diagungkan manusia sejak zaman auflaerung atau masa pencerahan (abad 18). Ilmu pengetahuan dan teknologi yang dielu-elukan filsafat rasional (logika) memunculkan kemajuan di berbagai bidang pembangunan manusia, namun serentak pada saat yang sama membawa kemunduran/ketidakmajuan dalam pembangunan yang tampil dalam wajah alam yang rusak dan memprihatinkan. Mestinya kemajuan/kebaikan manusia dibarengi juga dengan kemajuan dalam kebaikan alam. Akan tetapi, hal ini masih jauh sekali dari harapan dan 
kenyataan riil kehidupan manusia. Fenomena miris seperti inilah yang memunculkan kritik atas perilaku salah dan cara berpikir keliru manusia.

Banyak kritik sudah dialamatkan kepada filsafat rasional (logika) yang tidak memedulikan masa depan lingkungan alam bumi. Salah satu pemikir yang gencar menyerang filsafat rasional yakni Skolimowski. Skolimowski (1992) mengkritik cara berpikir rasional (logika) dan ilmu pengetahuan modern yang cenderung mekanistik-reduksionistik berujung pada tindakan pengrusakan atas lingkungan alam. Karena itu Skolimowski memperkenalkan suatu paradigma pikir baru yang disebutnya eko-filosofi (eco-philosophy). Kekuatan utama prinsip eko-filosofi yakni cara berpikir baru yang melihat alam secara spiritual-rohaniah. Maka dari itu, eko-filosofi sama arti dan substansi dengan sebuah eco-spiritual (spiritualitas lingkungan alam) baru demi kebaikan alam dan lingkungan hidup itu sendiri. Di titik ini dibutuhkan sebuah kesadaran kritis untuk me-review sikap, pola pikir, dan tindakan/perilaku yang sudah terlanjur diaplikasikan selama ini; bahwa sesungguhnya manusia sudah salah jalan dan menyimpang jauh dari hakikat kemanusiaan sebagai makhluk spiritual. Maka diagnosis masalah utama krisis lingkungan alam dewasa ini yakni orientasi manusia yang hanya terarah pada pemenuhan kebutuhan ekonomis semata-mata namun pada saat yang sama mensekunderkan/memarginalkan nilai-nilai hakiki spiritual dalam relasi dengan lingkungan alam. Inilah akar utama krisis lingkungan alam manusia pada era kontemporer saat ini.

\section{Spiritualisme sebagai Alternatif Solutif Masalah Lingkungan Alam}

\section{Alam Semesta, Tanda Kehadiran Tuhan}

Semua spiritualisme (juga tentu agama) memiliki keyakinan hakiki bahwa lingkungan alam termasuk manusia di dalamnya adalah ciptaan Tuhan yang indah dan baik adanya sejak mulanya. Adanya dunia dan proses evolusi dalam dinamika waktu panjang tidak mengurangi kualitas nilai luhur alam semesta. Lingkungan alam tempat manusia hidup merupakan sebuah realitas bernilai intrinsik pada dirinya sendiri (in se). Nilai intrisisme alam tidak ditentukan oleh manusia, namun memiliki nilai internal pada dirinya sendiri sejak diciptakan Tuhan. Nilai intrinsik lingkungan alam diberikan Tuhan sejak proses penciptaan dan berlangsung sampai sekarang dan hingga ke masa depan, ke anak cucu. Manusia tidak berhak sedikit pun menentukan nilai/martabat lingkungan alam. Lingkungan alam adalah kenyataan terberikan oleh Tuhan untuk manusia. Karenanya lingkungan alam adalah hadiah/rahmat (gabe) istimewa Tuhan yang patut disyukuri manusia dengan penuh rasa tanggung jawab (aufgabe). Bentuk syukur kepada Tuhan tersebut patut direalisasikan dalam wujud sikap tanggung jawab spiritual manusia untuk menjaga dan melestarikan lingkungan alam.

\section{Peran Tuhan di Ladang}

Sebuah penelitian dilakukan oleh satu akademi pertanian tentang produksi 3640 liter jagung di ladang seluas 1 hektar. Manusia menyumbangkan tenaganya. Tuhan menyumbangkan beberap hal juga: 4 juta pon air, 6800 pon oksigen, 5200 pon karbon, 1900 pon karbon dioksida, 160 pon nitrogen, 125 pon potasium, 40 pon fosfor, 74 sulfur kuning, 50 pon magnesium, 50 pon kalsium, 2 pon besi dan sejumlah partikel kecil iodine, seng, tembaga dan lain-lain. Dan semuanya itu berada di dalam 3640 liter jagung. Siapa yang membuatnya? (Mihalic, 1996)

Tuhan berperan tak terlihat menjadikan segala proses yang terjadi di dalam alam ini berlangsung dan mencapai hasil yang indah, tepat, efektif, efisien dan sempurna pada waktunya. Tak satu pun yang tahu bahwa Tuhan bekerja dengan cara yang agung dan mengagumkan sekali. Tuhan meracik berbagai unsur (elemen) di dalam alam semesta dan menciptakan berbagai jenis makhluk hidup termasuk tumbuhan bebijian seperti jagung dalam kutipan Mihalic (1996).

Alam adalah ciptaan Tuhan yang sungguh indah dan luar biasa tak terselami logika akal budi manusia. Manusia pantas bersyukur atas pesona keindahan yang diberikan Tuhan ini. Bentuk rasa 
syukur itu dapat manusia ekspresikan dan eksplisitasikan dalam untaian doa dan syair spiritual-religius kepada Tuhan, Sang Pemberi Kehidupan; seperti tergambarkan dalam contoh syair berikut.

Terima Kasih untuk Bumi

Terima kasih, ya Tuhan untuk bumi yang hijau

Tak dapat dibayangkan dunia ini tanpa lumut dan rerumputan

Tanpa ilalang dan pepohonan

Tanpa kembang dan bebuahan

Terima kasih, ya Tuhan untuk pohon-pohon

Yang memagar pantai dan menghijaukan pegunungan

Yang kami tebang untuk membangun

Rumah, jembatan dan perkantoran

Terima kasih, ya Tuhan untuk hutan yang menahan erosi

Yang menyuburkan tanah

Dan yang mendatangkan batu bara dan minyak tanah

Terima kasih ya Tuhan untuk dedaunan yang menyedot polusi

Dan memberi kami zat untuk bernapas

Yang dapat kami olah menjadi

Sambal, lalapan, tahu, tempe dan kangkung cah

Terima kasih ya Tuhan untuk bunga-bunga yang menghias taman dan kamar

Yang dapat kami hadiahkan kepada kekasih tanda cinta dan kesetiaan

Yang dapat kami taburkan di atas pusara

Tanda kasih dan sayang, kenangan dan persahabatan

Terima kasih ya Tuhan untuk buah mangga dan buah salak

Untuk buah durian dan buah segala buah. Amin (Lalu, 1984).

Manusia spiritual yang bijak adalah manusia yang memiliki visi jauh dan intuisi mendalam untuk menjaga panorama alam sebagai hadiah terindah Tuhan bagi manusia. Bahwa alam bukan semata-mata terberi untuk dieksploitasi bagi kebutuhan manusia, melainkan alam hadir sebagai samasama ciptaan seperti manusia yang ikut membuktikan jejak kehadiran Tuhan di dalam jagad makrokosmos ini. Karena itu alam patut pandang sebagai realitas bermakna spiritual. Alam adalah salah satu cara kesaksian tentang hakikat Tuhan sebagai Maha Pencipta yang Luhur-Agung.

Segala kehidupan yang berlangsung di alam berlangsung dalam Tuhan dan kelak akan kembali ke fitrah, ke pangkuan Ilahi Tuhan juga. Filsuf Teilhard de Cardin mengatakan hidup adalah gerakan dari Tuhan sebagai titik awal (alfa) menuju titik akhir (omega) dalam hakikat Tuhan sendiri. Karena itulah saatnya manusia menyadari kebenaran spiritual ini dan menghayati relasi dengan lingkungan alam dalam suatu hubungan spiritual manusia pada Tuhan Sang Pencipta alam semesta.

\section{Eko-Spiritualisme bagi Masyarakat Manusia, Sebuah Urgensi}

Eko-spiritual memberikan suatu imperatif spiritual bagi manusia untuk kembali menghargai nilai-nilai intrinsik yang sudah mengkristal di dalam lingkungan alam. Eko-spiritual melecut titik kesadaran manusia untuk mengembalikan nuansa keindahan dan pesona alam yang luar biasa, namun yang kini telah meluntur nuansanya karena logika rasional yang keliru dan tindakan tak etis-destruktif manusia. Saatnya manusia melakukan total action (gerakan menyeluruh) untuk kembali ke alam (back to nature). Gerakan ini bukan hanya untuk segelintir orang namun harus menjadi gerakan seluruh masyarakat dunia semua pihak mulai dari individu, unsur politik, pengambil kebijakan ekonomi (terlebih kaum kapitalis), akademisi, masyarkat luas tidak secara terpisah-pisah (terkotak-kotak), tetapi dilakukan secara holistik-menyeluruh. Gerakan ini harus menjadi gerakan semua orang di bumi yang 
masih memiliki hati untuk peduli pada kebaikan lingkungan alam universal. Jika tidak, manusia akan kehilangan kesempatan untuk menyelamatkan lingkungan alam dan kiamatlah ekosistem bumi.

Tentu bagi kelompok orang yang menghayati spiritualisme (termasuk agama), eko-filosofi bisa menjadi sebuah kewajiban/kesadaran moral spiritual yang dipakai sebagai modal paradigmatif efektif untuk mengubah cara pikir keliru pada lingkungan alam. Manusia telah berdosa terhadap alam dengan kejahatan-kejahatan ekologis seperti menebang pohon, membuang sampah sembarangan, merambah hutan secara liar, mengotori air, mempolusikan udara, dan sebagainya. Perlu dilakukan sebuah metanoia ekologis (pertobatan lingkungan) untuk mengembalikan keindahan dan kesakralan alam semesta. Cara pikir yang sudah berhasil diubah, niat luhur yang sudah mengkristal kukuh dalam hati, ditunjukkan juga dalam komitmen tindak-nyata untuk membangun relasi yang lebih etis, estetis, humanis, dan harmonis dengan lingkungan alam. Sesudahnya, bersama-sama menyongsong sebuah tatanan dunia baru yang bebas dari krisis ekologis; menyambut masa depan ekologi bumi yang semakin baik dan ideal.

\section{Peduli pada Lingkungan Alam, Sebuah Imperatif Spiritual}

Sudah diklaim pada bagian sebelumnya bahwa manusia telah berdosa terhadap alam dengan merusakkan kebaikan dan keindahan alam melalui berbagai tindakan eksploitasi yang merusak. Tindakan destruktif oleh manusia pada alam sebetulnya merupakan potret pengrusakan juga terhadap diri ekologis manusia sendiri karena manusia juga memiliki kualitas kehidupan di dalam dirinya sendiri (unsur biotik-vegetatif). Merusakkan alam sama artinya dengan pengrusakan/pembinasaan paling tragis atas kualitas kehidupan yang melekat erat pada manusia sendiri. Dengan kata lain, sebetulnya manusia sudah secara tak langsung mulai melakukan proses bunuh diri pada dimensi kemanusiaan itu sendiri. Di sinilah esensi kemanusiaan digugat dan dipertanyakan. Maka dari itu diperlukan sebuah kesadaran dasar untuk kembali peduli pada lingkungan alam. Peduli pada alam sama nilainya dengan penghargaan kembali pada martabat/nilai kemanusiaan itu sendiri.

Adalah benar secara spiritual bahwa lingkungan alam adalah ciptaan /anugerah Tuhan terindah dan teristimewa bagi umat manusia di bumi. Skolimowski (1992) menunjukkan secara jelas pandangan ekologisnya tentang nilai-nilai luhur lingkungan alam sebagai substansi dasar yang kudus, suci, dan sakral. Manusia harusnya berperan menjaga sakralitas alam dengan mengembangkan sikapsikap positif untuk melindungi alam yang bernilai mulia-luhur. Konsep sakralitas alam ini sangat relevan digunakan sebagai usaha etis untuk melecut motivasi spiritual manusia menata kembali hubungan manusia dengan lingkungan alam. Motivasi spiritual ini perlu dipahami, dihayati, dan direalisasikan dalam praktik hidup harian. Kesadaran ini penting bagi manusia untuk mulai dengan langkah awal berani mengembangkan sikap peduli pada kebaikan lingkungan alam.

Jika kesadaran spiritual sudah ada di dalam diri, manusia perlu mulai melakukan gerakan nyata untuk peduli pada lingkungan. Jadi bukan sekadar retorika atau wacana bualan omong kosong belaka, dan mau melakukan hal-hal nyata-aplikatif untuk menjaga, memulihkan, dan menyelamatkan masa depan lingkungan alam dari ancaman kerusakan parah atau pun ancaman kepunahannya yang makin besar. Itu artinya manusia bukan sekadar memiliki rasa prihatin atau peduli saja, melainkan harus menunjukkan rasa hormat etis dan respek spiritual pada alam. Rasa hormat etis dan respek spiritual ini merupakan realisasi dari semangat empati dan kepedulian manusiawi pada lingkungan alam. Hormat dan respek spiritual mendorong manusia untuk selalu memandang dan memperlakukan alam sebagai unsur yang bernilai rohani daripada sekadar realitas fisik-material. Manusia perlu memiliki visi spiritual pada alam.

Pandangan yang spiritual terhadap alam akan memunculkan sikap-sikap yang humanis, etis, bermoral, integratif, holistik dan menyeluruh. Manusia diingatkan untuk mewaspadai konsep-konsep logis-rasional dan teknis-mekanistik belaka sebagaimana yang diusung filsafat analitis, empirik, dan sains modern yang cenderung memandang alam sebagai realitas fisik yang dikuasai dan dieksploitasi. 
Manusia hendaknya melakukan re-thinking untuk kembali kepada alam (back to nature). Manusia ingin kembalikan pesona, eksotisme, dan sakralitas alam pada posisinya yang sebenarnya. Hanya dengan ini sikap kepedulian spiritual manusia pada lingkungan alam sungguh bermakna aktual dan mendalam. Manusia hendaknya memandang alam sebagai realitas spiritual yang bernilai intrinsik pada diri sendiri, dan bukan semata-mata sebagai realitas fisik-material. Inilah visi eko-spiritual yang perlu dihayati dalam praktik mulai sekarang ini.

Visi eko-spiritual digunakan sebagai paradigma pikir yang mau direalisasikan juga dalam realitas sosial. Visi eko-spiritual menjadi sebuah imperatif religius-spiritual bagi manusia atau siapa saja yang memiliki komitmen tinggi dan itikad baik menjaga dan melestarikan kawasan ekologis bumi. Visi eko-spiritual merupakan sebuah gerakan spiritualisme bersama semua pihak. Visi ini harus mulai diterapkan secara total mulai dari pihak lembaga pendidikan, tokoh agama, tokoh spiritual, tokoh masyarakat, dan semua unsur masyarakat dalam level apa saja. Visi ini harus menjadi total action semua orang orang beragama dan penganut spiritual jika berkomitmen luhur untuk menjaga kebaikan lingkungan alam. Visi eko-spiritual ini akhirnya menjadi bagian dari iman kaum beragama dan penganut spiritual dalam menghayati eksistensinya di planet bumi ini dalam mengembangkan relasi ideal dengan alam.

Namun usaha mengintegrasikan iman ke dalam tindakan kepedulian (care) pada alam tentu bukan tanpa masalah di zaman sekarang. Kita berhadapan dengan berbagai kekuatan ideologis raksasa dunia (politik, ekonomi, dan kapitalisme) yang melihat alam secara berbeda dengan yakinan kelompok agama dan spiritualis. Kita memiliki visi yang berseberangan dengan kelompok politisi, kaum kapitalis maupun ilmuwan yang kehilangan dimensi spiritualisnya dalam pendekatan dengan alam. Semuanya itu menjadi tantangan bagi manusia dalam merealisasikan visi eko-spiritualis itu. Manusia harus tetap semangat, optimistis, dan terus berjuang untuk menjadikan visi eko-spiritual sebagai pegangan dan komitmen dasar spiritual dalam menghayati iman kepada misteri Tuhan. Inilah panggilan spiritual manusia dalam dunia yang terancam kepunahannya sekarang ini.

\section{Mengembangkan Kepedulian pada Lingkungan, Langkah Praktis}

Visi eko-spiritual idealnya tidak hanya sampai pada cara berpikir, tetapi perlu diaktualisasikan secara nyata dalam aktivitas hidup sehari-hari. Ia perlu diekspresikan, ditunjukkan dan diwujudkan dalam hidup nyata. Visi ini harus tercermin dalam perbuatan yang hidup sebagai bentuk kesaksian yang paling otentik dalam tatanan dunia kontemporer ini.

Iman dalam konteks keyakinan spiritual, bukan hanya keyakinan pada Tuhan, melainkan juga perbuatan nyata pada sesama dan lingkungan alam. Iman tanpa perbuatan tak mungkin atau sia-sialah belaka karena iman tanpa perbuatan akan kehilangan relevansi praktisnya. Iman kepada Tuhan tidak hanya ditunjukkan dalam ritual ibadah atau perbuatan etis pada sesama, tetapi juga harus dinyatakan dalam relasi yang etis dengan alam. Di sinilah iman ekologis menjadi urgen. Iman ekologis bukan hanya soal masalah pengetahuan, keyakinan dan kata-kata saja. Iman ekologis menuntut realisasi di dalam praktis dalam bentuk perbuatan atau aksi konkret-nyata. Untuk itu manusia perlu segera bertindak! Saat ini yang lebih penting adalah keberanian bertindak nyata peduli pada alam daripada sebuah renungan bijak tentang alam. Lalu cara menunjukkan iman ekologis itu adalah sebagai berikut.

Pertama, menyadari lingkungan alam sebagai sumber kehidupan segala makhluk di dunia termasuk hewan dan manusia tentunya. Kesadaran ini wajib dihayati oleh setiap orang beragama dan penganut spiritual. Kesadaran akan nilai dasar lingkungan alam ini akan membuat manusia menghargai alam, menghormati alam, dan bertoleransi pada alam. Toleransi pada lingkungan alam artinya manusia membiarkan alam bertumbuh sesuai dengan tendensi alamiah di dalam dirinya sendiri, tanpa adanya intervensi berlebihan dari pihak manusia. Jika manusia menghidupkan lingkungan alam, lingkungan alam juga akan menghidupkan manusia dan seluruh makhluk. Sebaliknya jika manusia membunuh kehidupan alam, alam pun akan semakin sadis lagi 
membinasakan kehidupan manusia dan makhluk hidup lainnya. Jika manusia menjaga alam, alam pun akan menjaga manusia. Jika manusia tidak menjaga alam, alam pun tidak akan menjaga manusia. Kesadaran akan lingkungan alam sebagai sumber kehidupan akan mendorong manusia untuk rajin menanam pohon, tidak menebang hutan secara sembarangan, membuang sampah pada tempatnya dan sebagainya. Menyitir Korten (2006:47), “orang yang memiliki kesadaran spiritual akan menginsafi bahwa lingkungan alam merupakan integral world dan memaknai keberadaan dirinya sebagai partner aktif atau co-creator dalam melayani evolusi ciptaan untuk mengaktualisasikan kemungkinankemungkinannya.” Kesadaran spiritual membuat manusia melakukan tindakan-tindakan kreatif untuk menjaga keberlangsungan hidup alam semesta. Tentu dengan membiarkan alam merealisasikan dan mewujudkan dirinya secara bebas-otonom tanpa intervensi-dominatif manusia.

Kedua, melakukan gerakan minimalis dalam hidup nyata sehari-hari. Gerakan minimalis artinya manusia hanya butuh sedikit untuk hidup daripada butuh banyak. Manusia tidak perlu hidup maksimal dalam memperlakukan lingkungan alam. Manusia cukup mengambil sedikit manfaat saja dari alam tanpa proyeksi nafsu ekstrem untuk menguasainya, apalagi mengedepankan rasa rakus berlebihan untuk menghisap hasil lingkungan alam (bumi) secara sembarangan dan tidak wajar. Gerakan minimalis membuat manusia mencukupkan diri dengan hidup apa adanya, tanpa ambisi untuk menguras alam sebesar-besarnya. Gerakan minimalis harusnya terpancar keluar dalam sikap tidak boros dalam memanfaatkan sumber energi alam misalnya hemat air, hemat listrik, hemat menggunakan minyak bumi, bersepeda saja ke kampus atau tempat kerja, dan lainnya. Gerakan minimalis urgen dihayati secara konsisten dalam hidup mulai saat ini.

Ketiga, berani mengkritik kegiatan pembangunan yang tidak mendukung kebaikan lingkungan alam. Iman ekologis menuntut manusia untuk kritis pada segala usaha pembangunan yang tidak mendukung kebaikan lingkungan alam. Jika kelompok politik atau pun kaum kapitalis tidak memedulikan kebaikan/keselamatan lingkungan alam, kelompok spiritualis dan kelompok agama perlu menyuarakan suara kritis menegakkan nilai-nilai kebaikan ekologis. Jika ada penjahat lingkungan yang masih saja melakukan kejahatan ekologis, perlu mendeklarasikan nilai yang berseberangan dengannya. Diperlukan kritis pada orientasi pembangunan yang tidak pro-life dan gagasan pembangunan berkelanjuntan. Kejahatan ekologis akan terus berkembang jika kelompok agama dan spiritual tidak melakukan tindakan apa pun untuk menyelamatkan bumi. Artinya, manusia tidak boleh diam menyaksikan eksploitasi lingkungan yang merusak terus terjadi di depan mata. Manusia perlu berani melakukan kritik-positif sebagai komitmen mulia untuk menjaga kebaikan lingkungan alam demi keutuhan dan kebaikan bumi.

Keempat, mengembangkan hubungan yang spiritual dengan lingkungan alam. Lingkungan alam perlu dipandang sebagai realitas bernilai spiritual pada dirinya sendiri. Visi ini mendorong manusia untuk menghargai kesucian, kekudusan, dan kekeramatan intrinsik yang melekat pada alam. Sejarah sudah membuktikan bahwa pengrusakan alam terjadi ketika manusia tidak menghargai lagi kesucian alam. Maka usaha menjaga dan melestarikan alam hanya bisa dilakukan jika melihat alam sebagai realitas yang suci di dalam dirinya sendiri. Visi ini akan mencegah manusia untuk mengeksploitasi alam secara membabi-buta untuk kepentingan egoistik manusia. Sudah saatnya manusia membangun, menjaga, dan melestarikan pola relasi baru dengan alam dalam nuansa spiritual. Pola hidup spiritual seperti ini akan memunculkan semangat respek yang tinggi pada lingkungan alam sebagai realitas keramat yang mutlak dilindungi nilai dan martabatnya. Pola relasi spiritual dengan alam membuat manusia melakukan tindakan-tindakan positif untuk menjaga kebaikan, keindahan, dan kesucian alam tanpa berikhtiar untuk memburukkan, menjelekkan, dan menodai lingkungan alam.

\section{Hasil Akhir Spirit Kepedulian pada Lingkungan Alam}

Pada bagian sebelumnya sudah dipaparkan tentang cara-cara yang dapat dikembangkan untuk menunjukkan sikap peduli pada lingkungan alam. Semua upaya tersebut tentu sangat bermanfaat positif bagi terciptanya situasi masa depan alam yang lebih baik lagi dibandingkan sekarang ini. Buah- 
buah dari sikap peduli pada lingkungan alam dimaksud bisa diproyeksikan dalam lima pokok pikiran berupa pengondisian masa depan alam yang lebih baik lagi, yakni: terciptanya situasi lingkungan alam yang seimbang (ekuilibrasi), terciptanya situasi keadilan terhadap alam (yustisial), terciptanya situasi kebaikan alam (etika), terciptanya situasi keindahan alam (estetika), terciptanya kondisi sakralitas alam (spiritualisme).

Pertama, terciptanya lingkungan alam yang seimbang. Jika cara-cara peduli pada alam diterapkan secara konsisten dan konsekuen, akan tercipta lingkungan alam yang seimbang. Keseimbangan yang dimaksud di sini artinya kerusakan alam yang signifikan dan dampaknya yang merusakkan kehidupan manusia dan makhluk lain akan semakin berkurang atau bisa diminimalkan. Sebuah surga di dunia dalam kondisi lingkungan alam yang seimbang dan harmonis ingin diciptakan kembali sejak sekarang di dunia fana ini. Alam yang seimbang tampak dalam berkurangnya bencana alam banjir, angin topan, badai ganas, krisis energi, pemanasan global, tanah longsor, dan sebagainya. Peristiwa bencana alam akibat ulah manusia ingin dieliminasi sehingga manusia semakin nyaman tinggal di bumi.

Kedua, terciptanya situasi keadilan terhadap alam. Segala bentuk tindakan eksploitasi yang berlebihan pada alam menggambarkan perlakukan tidak adil manusia terhadap alam. Perlakuan tidak adil manusia pada alam menunjukkan kekuasaan manusia dan mengedepankan suatu bentuk kolonialisme baru (kriptokolonialisme) manusia pada lingkungan alam. Padahal, hidup manusia seluruhnya tergantung pada alam dan tidak mungkin tanpa lingkungan alam. Sikap peduli pada alam akan menciptakan sikap adil manusia pada alam yang selama ini tidak diperhatikan sama sekali. Sikap adil bukan hanya perlu diwujudkan dalam relasi antarmanusia, melainkan juga dalam relasi dengan alam. Keadilan pada alam artinya manusia mau kembalikan nilai-nilai intrinsik luhur yang sudah dirampas dari alam itu sendiri. Hal yang menjadi hak-hak alam untuk bertumbuh secara natural tanpa intervensi kekuasaan manipulatif berlebihan dari pihak manusia. Alam menentukan jalannya sendiri menuju kesempurnaan dirinya. Kesempurnaan alam terletak pada dirinya sendiri (inheren), dan tidak ditentukan oleh tanggapan indrawi-irasional ataupun keputusan rasional-logis manusia.

Ketiga, terciptanya situasi kebaikan alam. Alam yang tetap dalam kondisi terjaga baik menjadi arah atau orientasi dasar semua orang yang peduli pada alam. Tindakan peduli pada alam alhasil akan menghasilkan situasi ideal bagi kebaikan lingkungan alam itu sendiri. Alam yang dalam kondisi baik akan tampak dalam nuansanya yang asri, yang tersenyum, yang ramah dan bersahabat dengan manusia dan makhluk lainnya. Alam yang baik tidak akan memberikan bencana bagi kehidupan manusia dan makhluk lainnya di bumi ini.

Keempat, terciptanya situasi keindahan alam. Tindakan peduli pada alam akan menghasilkan kembali lingkungan alam yang indah. Lingkungan alam menjadi realitas surgawi bagi kita manusia. Lingkungan alam yang indah tampak dalam pemandangan alam yang menarik, hutan-hutan lebat menghijau, burung berkicau di atas pohon, hingga embun yang bercahaya pada dedaunan. Situasi indah alam memancarkan pesona eksotis yang menenteramkan hati dan menghidupkan berbagai makhluk hidup. Keindahan alam ibarat ibu yang memberikan rasa nyaman dan kebahagiaan batin bagi manusia yang mampu merasakan nilai estetis. Santo Agustinus pernah bermadah: "Lihatlah keindahan bumi, lihatlah keindahan samudera, tanyakanlah keindahan udara yang menyebarluas, tanyakan keindahan langit, tanyakanlah semua benda dan makhluk; dan semuanya akan menjawab: lihatlah betapa indahnya kami, siapakah yang menciptakan benda-benda yang indah di dunia ini kalau bukan Yang Ilahi? (Leteng, 2005:24). Keindahan alam adalah hasil ciptaan Tuhan yang perlu dipelihara dan dilestarikan eksistensinya oleh manusia. Dan ini hanya mungkin jika manusia memiliki intuisi dan visi spiritual untuk peduli pada alam.

Kelima, memulihkan sakralitas alam. Tindakan eksploitatif manusia pada alam telah mengggeruskan sakralitas alam. Dan manusia mau peduli pada alam untuk memulihkan sakralitas alam itu. Salah satu hasil atau buah penting dari tindakan peduli pada lingkungan alam tampak dalam 
kondisi alam yang sakral, kudus, suci. Alam yang sakral sungguh bernilai luhur dan mulia serta kudus karena diciptakan oleh Tuhan sendiri. Sebagai ciptaan Tuhan, alam memiliki kualitas keilahian dan kekudusan di dalam dirinya sendiri. Kualitas sakral ini patut diinsyafi oleh setiap manusia yang masih punya hati nurani yang murni-bening. Sikap peduli pada lingkungan alam harus dilandasi oleh iman ekologis yang tinggi dan mendalam pada alam sebagai ciptaan Tuhan yang bernilai agung-luhur.

\section{SIMPULAN}

Sudah dipahami bersama bahwa akar utama krisis lingkungan alam menohok pada cuatan paradigma pikir keliru dan ekspresi pola sikap/tindakan salah terhadap alam. Sesat pikir (falasi) ini muncul karena manusia memandang alam sebagai realitas fisik yang selalu perlu dieksploitasi secara teknis untuk memenuhi kebutuhan manusia semata-mata. Pola relasi manusia dengan alam jadinya self-oriented dan antroposentris. Relasi manusia dengan lingkungan alam terdistorsi. Relasi ini akhirnya harus dibayar mahal oleh manusia kontemporer yang semakin menderita akibat diterpa berbagai berbagai fenomena miring alam yang sangat menggelisahkan mulai dari polusi di tanah hingga menipisnya lapisan ozon di langit.

Paradigma keliru manusia terhadap alam yang sudah dianut beratus tahun lamanya telah dideklarasikan oleh dunia sains modern, teknologi canggih dan ekonomi kapitalistik yang dominaneksploitatif. Subjek manusia kehilangan kesejatiannya karena hanyut dalam rayuan gombal dogma tekno-ekonomis yang merusakkan lingkungan alam. Dimensi jiwa-spiritual manusia semakin termarginalkan karena manusia hanya memerhatikan urusan tubuh (badan) yang terepresentasi dalam kebutuhan-kebutuhan manusia untuk survive. Saatnya sebuah kesadaran kritis baru untuk memandang alam dan memperlakukannya dengan cara baru. Cara baru memandang alam itu muncul dari sisi spiritual manusia dalam relasinya dengan lingkungan alam. Ya, sebuah eko-spiritual mutlak dihayati oleh umat manusia kontemporer jika ingin menyelamatkan generasi masa depan anak cucu kita. Sebab kalau bukan sekarang, kapan lagi. Dan kalau bukan kita, ya siapa lagi.

\section{DAFTAR PUSTAKA}

Binawan, L., Al, A. (2010). Homo Eco-Religiosus. Diskursus. Volume 9, No. 2, Oktober 2010, pp. 193-211.

Korten, C. D. (2006). The Great Turning from Empire to Earth Community. San Francisco: Berrett-Koehler Publisher \& Kumaran Press.

Lalu, Y. (1984). Kembali ke Desa-Tinggal di Desa. Jakarta: Komkep KWI.

Leteng, H. (2005). Filsafat dan Spiritualitas. Jurnal Ledalero, Vol. 4 No. 2.

Mihalic, F. (1996). 1500 Ceritera Bermakna 1. Jakarta: Obor.

Skolimowski, H. (1992). Living Philosophy: Eco-Philosophy as A Tree of Life. London: Arkana/Penguins Books

(1992). Eco-Philosophy, the World is a Sanctuary. 